\title{
Factors Impacting the Prevalence of Foodborne Pathogens in Agricultural Water Sources in the Southeastern United States
}

\author{
Camila Rodrigues ${ }^{1}$, Andre Luiz Biscaia Ribeiro da Silva ${ }^{2}$ and Laurel L. Dunn ${ }^{1, *(B)}$ \\ 1 Department of Food Science \& Technology, University of Georgia, Athens, GA 30602, USA; \\ crodrigues@uga.edu \\ 2 Department of Horticulture, University of Georgia, Tifton, GA 31793, USA; adasilva@uga.edu \\ * Correspondence: laurel.dunn@uga.edu
}

Received: 18 November 2019; Accepted: 19 December 2019; Published: 21 December 2019

\begin{abstract}
Surface water poses a great risk to fruit and vegetable crops when contaminated by foodborne pathogens. Several factors impact the microbial quality of surface waters and increase the risk of produce contamination. Therefore, evaluating the factors associated with the prevalence of pathogenic microorganisms in agricultural water sources is critical to determine and establish preventive actions that may minimize the incidence of foodborne outbreaks associated with contaminated production water. In the Southeastern U.S. environmental factors such as rainfall, temperature, and seasonal variations have been associated with the prevalence of pathogens or microbial indicators of fecal contamination in water. Also, the geographical location of the irrigation sources as well as surrounding activities and land use play an important role on the survival and prevalence of pathogenic bacteria. Therefore, these factors may be determinants useful in the evaluation of production water quality and may help to preemptively identify scenarios or hazards associated with the incidence of foodborne pathogenic microorganisms.
\end{abstract}

Keywords: irrigation water; surface water; Escherichia coli; Salmonella; food safety

\section{Introduction}

Approximately 48 million people in the U.S. are subject to foodborne illnesses every year, and nearly half of these cases are associated with the consumption of contaminated fresh produce [1,2]. In recent years, several foodborne outbreaks linked to irrigation water have occurred due to produce contamination. For example, Salmonella serotype St. Paul was isolated from the environment and agricultural water in a 2008 jalapeno and serrano pepper outbreak that resulted in approximately 1500 cases of Salmonellosis [3]. In 2010, alfalfa sprouts contaminated by Salmonella serotype I 4, 5, 512:i:caused a multistate outbreak that sickened 140 individuals and resulted in hospitalization for $24 \%$ of those cases; the outbreak strain was isolated from water runoff [4]. In 2015, a recurrent multistate Salmonella serotype Newport outbreak was linked to contaminated surface water used to irrigate tomato crops [5]. In the same year in Sweden, an outbreak of E. coli O157:H7 infections associated with lettuce consumption was linked to contaminated river water used for irrigation [6]. In December 2018, a farm in Santa Maria (California) recalled red and green leaf lettuce and cauliflower after an E. coli O157:H7 outbreak resulted in 62 illnesses and 25 hospitalizations throughout the U.S. and Canada [7,8]. In this outbreak, untreated surface water was the primary source for irrigation, highlighting the importance of microbial monitoring. An increase in the consumption of fresh, minimally processed fruits and vegetables as a way to adopt a healthier lifestyle is resulting in increased pressure on growers to improve food safety practices in order to reduce consumer exposure to pathogens on 
produce [9]. However, fresh produce continues to be a significant source of foodborne outbreaks and a major food safety challenge. Foodborne outbreaks are not only a public health concern but also result in substantial financial losses throughout the food industry and particularly for producers of associated commodities [10]. To address these issues, in 2016 the U.S. Food and Drug Administration (FDA) established the Produce Safety Rule (PSR) within the Food Safety Modernization Act (FMSA) to improve the safety of produce during pre- and postharvest activities for commodities that are normally consumed raw [11].

In order to meet the growing nutritional demands required to feed the world's projected population of 9 billion people by 2050, agricultural production must increase substantially. This increased agricultural activity has, in part, contributed to elevated microbial and chemical contamination of soil and water [12]. States in the Southeastern U.S. are increasing their use of surface water as the primary source for irrigation in agriculture. This is partially due to easier access to lakes, rivers, ponds, springs, and creeks than groundwater aquifers, as well as lower initial costs to set up irrigation systems from surface water. However, surface water is more susceptible to microbial contamination than most groundwater sources due to its exposure to the environment [13]. Microorganisms that cause human disease, such as Shiga-toxigenic E. coli (including E. coli O157:H7), Salmonella enterica, Campylobacter spp., Shigella spp., Cyclospora cayetanensis, and others, may be present when water is contaminated by animal or human feces [14,15]. Because microorganisms can easily be transferred to produce, and because they have some tolerance to a myriad of environmental stressors (e.g., solar radiation, nutrient competition, predation, changes in $\mathrm{pH}$, and temperature), elucidating accurate indicators that may be used to predict the microbial quality of surface water sources is critical to prevent initial produce contamination and protect public health. Management of water resources is challenging because a multitude of factors can result in fluctuations of pathogen prevalence and concentrations throughout the growing season, including geographical location, land use, surrounding activities, migration patterns, and environmental factors [14]. The objective of this review is to summarize the topics related to the microbial quality of agricultural water and identify the main factors associated with the contamination of water sources used for fresh produce irrigation throughout the Southeastern U.S.

\section{Water as a Vehicle for Foodborne Pathogen Transmission during Crop Production}

The climates of Florida, Georgia, Alabama, Tennessee, South Carolina, and North Carolina, where most of the fruit and vegetable production in the Southeastern U.S. occurs, are classified as "humid subtropical" and characterized by having warm temperatures with high precipitation during the summer and cool temperatures with dry periods during the winter [16]. Most produce is grown during the spring and fall seasons, when weather conditions allow for proper crop development. Table 1 shows the acreage of produce harvested in the Southeastern U.S. in 2017, broken down by commodity, according to the U.S. Department of Agriculture (USDA) National Agricultural Statistics Service. States throughout this region receive an average 1200-1300 mm of rainfall annually [17-19]. However, the variability of precipitation and the influence of extreme weather events including hurricanes, floods, ice storms, and droughts make it difficult for produce growers to rely exclusively on rainfall. Most produce growers are therefore required to frequently irrigate their fields in order to substantially increase yields [20].

Several irrigation methods are utilized in the Southeastern U.S. but the most commonly used are overhead sprinkler irrigation, drip irrigation, and subirrigation [20]. These methods can directly affect the microbiota of irrigated crops [21,22]. For example, overhead sprinkler irrigation, in which water is applied on top of the crop canopy, results in water directly contacting the edible portion of a crop and therefore increases the likelihood of contamination if pathogens are present in the water [23]. Drip irrigation systems apply water to the root zone of the crop, which eliminates or reduces direct contact between irrigation water and produce, except in the case of root crops; because of this, this method is considered lower risk than sprinkler irrigation. For example, when irrigation water contaminated with E. coli was applied using an overhead sprinkler system, the prevalence of E. coli on produce increased 
by about 50\% when compared to contaminated water applied using a drip irrigation system [24]. In subirrigated fields, water levels are manipulated to raise the water table, resulting in indirect water application to the crop root zone due to a soil upward water flux from the water table [25]. The likelihood of microbial contamination to produce when using subirrigation methods is considered minimal [26]. When selecting irrigation methods, growers must weigh not only cost and practicality of each system for their operations, but should also consider the microbial risks from their water sources and when systems that minimize water contact with the produce are advisable. In a field experiment with cantaloupes, iceberg lettuce, and bell peppers, the likelihood of microbial contamination was one to two orders higher when using furrow irrigation compared to the subsurface drip method for all crops. Also, lettuce was more vulnerable to contamination than bell peppers [22]. In another study, the number of lettuce heads contaminated with E. coli O157:H7 after a single irrigation event was higher for sprinkler irrigation than the surface irrigation method. Additionally, E. coli O157:H7 persisted on the plants for 20 days after irrigation, and plant submersion in chlorinated water did not remove or inactivate the pathogen [27]. Both studies demonstrated that regardless of the irrigation method, crops can become contaminated when using irrigation water of poor quality.

Table 1. Acreage of produce harvested (vegetables, fruits, and nuts) by state in the Southeastern U.S. in 2017.

\begin{tabular}{|c|c|c|c|c|c|c|}
\hline Commodity & Florida & Georgia & Alabama & Tennessee & $\begin{array}{c}\text { South } \\
\text { Carolina }\end{array}$ & $\begin{array}{l}\text { North } \\
\text { Carolina }\end{array}$ \\
\hline & \multicolumn{6}{|c|}{ Harvested area (acres) } \\
\hline \multicolumn{7}{|l|}{ Vegetables } \\
\hline Cabbage & 9156 & 3647 & 46 & 143 & 192 & 2618 \\
\hline Broccoli & 1317 & 316 & 19 & 33 & 886 & 590 \\
\hline Squash & 7492 & 2757 & 1396 & 1692 & 1588 & 2801 \\
\hline Melons * & 2436 & 3324 & 518 & 266 & 902 & 1134 \\
\hline Cauliflower & 354 & 12 & 5 & 15 & 12 & 17 \\
\hline Cucumber & 26,222 & 6140 & 5367 & 253 & 984 & 9568 \\
\hline Tomato & 29,136 & 2648 & 1402 & 3281 & 2805 & 3057 \\
\hline Spinach & 767 & $\mathrm{~N} / \mathrm{A}$ & 1 & $\mathrm{~N} / \mathrm{A}$ & 18 & 52 \\
\hline Peppers & 11,739 & 3398 & 471 & 235 & 1116 & 1931 \\
\hline Lettuce & 9309 & 48 & 19 & 73 & 32 & 323 \\
\hline Greens $^{\dagger}$ & 1171 & 5723 & 425 & 1365 & 6648 & 2168 \\
\hline \multicolumn{7}{|l|}{$\begin{array}{c}\text { Fruits and } \\
\text { Nuts }\end{array}$} \\
\hline Peach & 904 & 9871 & 1348 & 464 & 13,917 & 758 \\
\hline Citrus $\ddagger$ & 446,044 & 149 & 153 & $\mathrm{~N} / \mathrm{A}$ & 1 & $\mathrm{~N} / \mathrm{A}$ \\
\hline Berries $\S$ & 17,054 & 19,427 & 1098 & 1164 & 1589 & 10,589 \\
\hline Pecan & 6476 & 133,786 & 8840 & 206 & 2580 & 896 \\
\hline Apple & 51 & 558 & 209 & 886 & 202 & 5214 \\
\hline Grape & 1157 & 1861 & 509 & 747 & 684 & 2521 \\
\hline
\end{tabular}

Source: USDA National Agricultural Statistics Service [28]. ${ }^{*}$ Melons includes watermelons and cantaloupes. ${ }^{\dagger}$ Greens includes collard, kale, mustard, and turnip. ${ }^{\ddagger}$ Citrus includes oranges, grapefruits, and tangerines. ${ }^{\S}$ Berries includes blackberries, blueberries, cranberries, strawberries, and raspberries.

Sources of irrigation water in Florida, Georgia, Alabama, Tennessee, South Carolina, and North Carolina include groundwater, surface water, and reclaimed water, with estimated uses of 2020, 1896, and 195 million gallon per day, respectively [19]. Groundwater is most typically drawn from deep wells; however, shallow wells are common in areas with shallow aquifers, such as in the Floridian Aquifer system. Water from these shallow wells may contain elevated levels of nitrate leached from agricultural production, as well as increased microbial contamination [29]. Additionally, the high-volume of pumped water for irrigation purposes in agriculture, particularly in areas using subirrigation systems where high volumes of water are required to manage the water table level, can change the direction 
and flow of groundwater, increasing the risk of contamination from the land surface into aquifers [29]. The quality of surface water, which includes lakes, rivers, ponds, springs, and creeks, fluctuates due to wastewater discharge, agricultural or urban runoff, domesticated and wild animal intrusion, human waste, and other contributing factors [14]. Consequently, the use of surface water is considered a higher risk practice than groundwater [30], which, when properly managed is less prone to contamination [14]. Reclaimed water is sourced from domestic or industrial wastewater that receives treatment and disinfection [19]. Reclaimed water poses fewer microbial risks than other water sources but may pose chemical hazards [31]. For this reason, several states have determined that reclaimed water should only be indirectly applied to vegetable crops that may be consumed raw via drip and subirrigation; in other words, reclaimed water contact with fresh produce is not advised [32]. Overall, understanding the source and cycle of water is fundamental to the safe and sustainable use of this important resource [29].

\section{Regulations, Guidelines, and Microbial Quality Standards for Agricultural Water}

In order to monitor the quality of water contacting fresh produce, systematic microbial water sampling schedules are critical. These programs should be based on current guidelines (good agricultural practices, quality assurance standards), third-party or buyer requirements, and current regulations, including the PSR [33]. To minimize the impact of foodborne outbreaks, the FDA established the PSR to improve the safety of fruits and vegetables that are normally consumed raw during growing, harvesting, packing, and holding activities. A primary goal of the FSMA was to shift the regulatory framework from a system that reacted and responded to foodborne outbreaks to a system focused on prevention and protection [11]. The PSR describes standards for good agricultural practices to which produce growers must adhere, including requirements for agricultural water used during pre- and post-harvest activities. FSMA defines "agricultural water" as water that is likely to contact the edible portion of produce that is covered by the rule, as well as water that may be used on food-contact surfaces; irrigation water accounts for the majority of pre-harvest water used on produce fields. The rule mandates testing schedules for the establishment of microbial water quality profiles (MWQP) for all water sources contacting the harvestable portion of the crop prior to harvest. To establish the MWQP, the surface water source is sampled for generic E. coli per $100 \mathrm{~mL}$ for 20 times over a 2 to 4 -year period, throughout the growing season including as close to harvest as practicable. In subsequent years, 5 additional samples are rolled into the MWQP. To comply with the PSR, the geometric mean for the MWQP must be $\leq 126 \mathrm{CFU} / 100 \mathrm{~mL}$ generic $E$. coli with a statistical threshold value of $\leq 410 \mathrm{CFU} / 100 \mathrm{~mL}$ generic E. coli [34]. In March 2019, the FDA extended the compliance dates for these agricultural water provisions by 4 years to give growers additional time to establish MWQPs for their water sources [35]. However, because timing of sample collection is left to the growers' discretion, some individuals may manipulate their MWQP by testing water sources at advantageous times, such as during periods of drought or late in the day when the water surface has been exposed to solar radiation for several hours, leading to results that may not be the most representative of the microbial water quality.

Certain produce types, such as leafy greens [22], appear to be more susceptible than other types to contamination and many enteric pathogens tend to preferentially attach to specific commodities. Salmonella, which has been implicated in multiple tomato and pepper-associated outbreaks [36-38], has resulted in no major U.S. outbreaks related to leafy green consumption [39]. Conversely, leafy greens are frequently associated with pathogenic E. coli outbreaks [7,40-46], but $E$. coli is seldom the causitive agent during outbreaks of enteric disease linked to tomatoes [36]. Pathogen attachment strength also varies among varieties within similar produce types; attachment of five S. enterica serovars was greater on Romaine lettuce than on Iceberg lettuce or cabbage [47]. Another study examining Salmonella attachment to produce germinated and grown in soil irrigated with an eight-serovar suspension found that incidence of Salmonella contamination was significantly lower on lettuce (51.1\% contamination incidence) and spinach (56.8\%), than other examined Asteraceae including radicchio $(86.6 \%)$ and endive $(79.6 \%)$. The authors also examined differences in contamination among tomato cultivars 
and found that contamination incidences ranged from $61.1 \%$ for the Brandywine cultivar, which was significantly higher than contamination incidence on the cultivars Nyarous (11.1\%) and Yellow Pear $(6.3 \%)$ [39].

\section{Microbial Indicators of Irrigation Water Contamination}

Monitoring microbial quality of water used in fruit and vegetable production is important to protect food safety [15]. Indicator bacteria such as generic E. coli are endemic to the intestinal tracts of warm-blooded animals, as are the pathogens Salmonella and Shiga-toxigenic E. coli. Therefore, the presence of generic E. coli in the environment suggests contamination by feces, which is a known reservoir of pathogenic microorganisms. To be considered a good fecal indicator, a microorganism should be found in the intestines of warm-blooded animals and not be naturally present in the environment, have similar survival rates as pathogens outside the host, be correlated with the presence of other pathogenic microorganisms, and less likely or slower to proliferate in the environment [27]. The FDA decided to rely on generic E. coli as the indicator of fecal contamination for agricultural use on PSR compliant farms based on previous scientific evidence. However, the appropriateness of using a single indicator to determine the microbial quality of water is still under examination [48].

In a recent study, a quantitative microbial risk assessment was conducted to identify potential contamination risks associated with foodborne pathogens on lettuce using different irrigation systems applying water in compliance with the PSR standards. Results showed that the risks of developing gastrointestinal (GI) illnesses when the water contains 126 CFU generic E. coli/100 mL corresponds to $0.000009 \%$ for subsurface irrigation systems, $0.0011 \%$ for furrow and $0.11 \%$ for sprinkler systems [30]. While the risk of illness from consuming lettuce containing $126 \mathrm{CFU}$ generic E. coli/100 mL seems relatively low, several other factors should be taken into consideration when examining the risks of foodborne illness. For example, in a study conducted in southern Georgia, both Salmonella and the indicator generic E. coli were found in farm ponds and irrigation systems; however, the concentration of generic E. coli found in the surface water was in accordance with PSR microbial water quality criteria [49]. This indicates that Salmonella may still pose a risk in waters that meet the PSR requirements. In a study conducted in southeast Georgia, the presence of $E$. coli O157:H7 was positively correlated with the concentration of fecal coliforms, but not generic E. coli, suggesting that a single indicator may not be adequate to assess the microbiological quality of irrigation water [50]. In addition, previous studies have demonstrated that generic E. coli does not correlate well with Salmonella [49,51-53], Campylobacter spp. [54], and E. coli O157:H7 [53,55] presence. It has also been reported that in subtropical and tropical areas, E. coli is an autochthonous organism in water rather than a fecal indicator [56]. Therefore, the use of generic $E$. coli as the sole indicator of agricultural water quality may lead to misinterpretation of the actual microbial quality and safety of water in some regions. The complexity of fecal indicators and pathogens makes such correlations a challenge in the effort to predict the safety of water sources.

\section{Current Status of Knowledge-Factors Affecting the Prevalence of Foodborne Pathogens in Surface Water in the Southeastern U.S.}

The use of surface water has been considered the primary issue related to water resource management [57], and contaminated irrigation water has been identified as a cause for several outbreaks of foodborne illness [15]. As previously mentioned, several factors, such as geographical location, land use, rainfall, temperature, seasonality, and water physicochemical characteristics can directly affect the microbial quality of water used in agricultural practices, which greatly impacts the risk of foodborne pathogen contamination on fresh produce. Previous studies that have examined microbial quality of production water sources in the Southeastern U.S. are summarized in Table 2 and will be discussed in more detail. Figure 1 illustrates the geographical location of the studies conducted in the Southeastern U.S. that are discussed within this review. Articles included in this section were peer-review publications that investigated environmental factors, geographical locations, land use, and physicochemical aspects related to microbial contamination of agricultural water sources within 
the six states discussed in this review. Databases such as PubMed, Web of Science and Google Scholar were used to search and review articles matching the keywords: Salmonella, E. coli, Campylobacter jejuni, coliforms, fecal contamination, irrigation water, agricultural water, surface water, watershed, wildlife, manure, rainfall, temperature, season, conductivity, water $\mathrm{pH}$, turbidity, water chemicals, Florida, Georgia, Alabama, Tennessee, North Carolina, South Carolina. Articles that investigated water sources not intended for agricultural use were not included in this review.

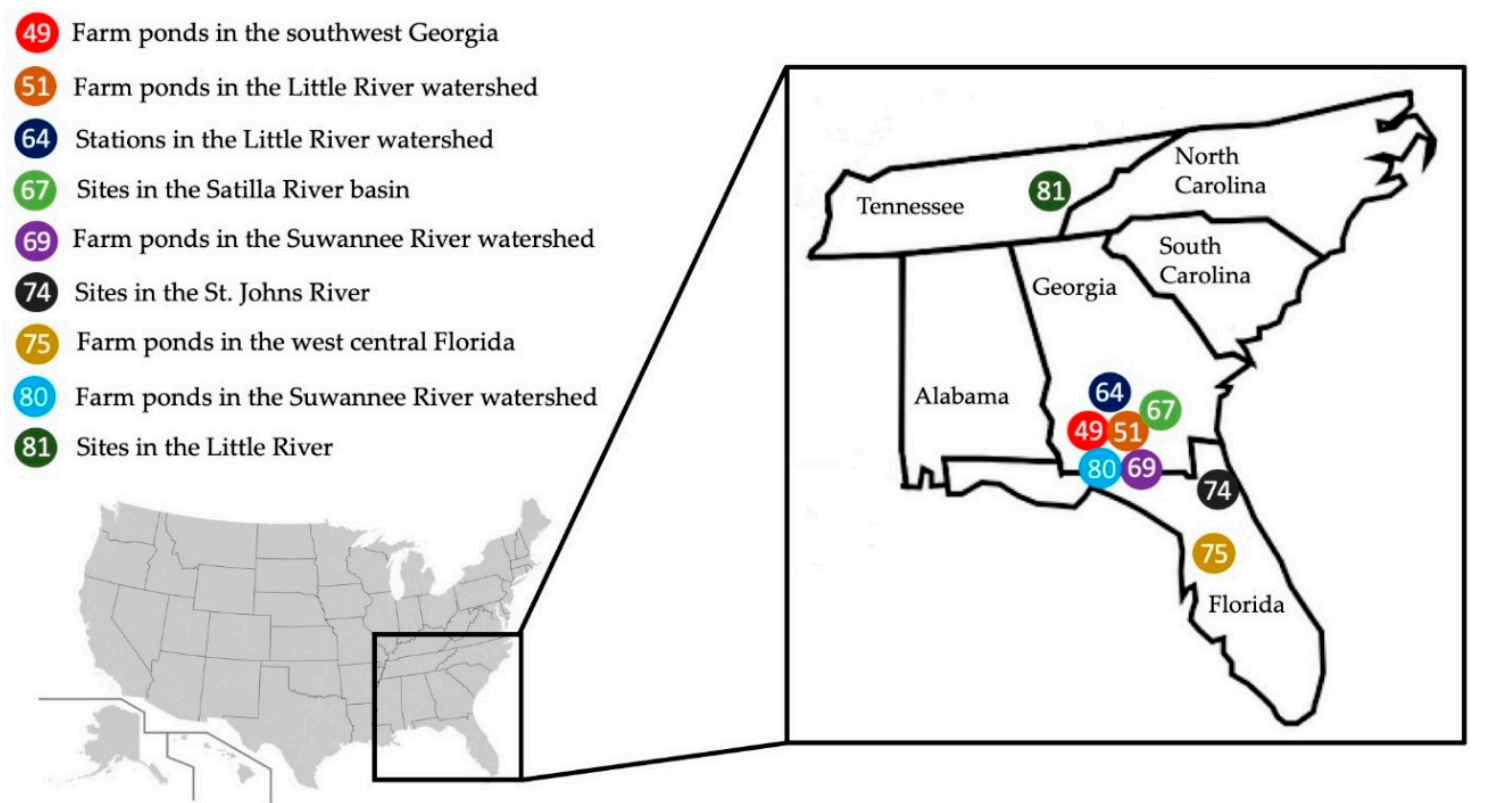

Figure 1. Geographical location of the studies conducted in the Southeastern U.S. Circled numbers represent the respective references linked to the study within the review.

\subsection{Rainfall, Geographical Location, and Bacterial Source Tracking}

Rainfall is an important factor that can increase the prevalence of pathogenic organisms in agricultural water, and particularly in surface waters. However, precipitation events can affect water sources variably within the same region, depending on the frequency of rain, topography, and location of the water source, including its proximity to livestock or urban pollution sources. Also, surface water can be directly contaminated by fecal material from humans and animals (both domesticated and wild), especially during heavy rainfall events or due to inadequate wastewater treatment [58]. Dairy farms frequently flush manure from barns into storage lagoons or separate the liquids from the solid material to facilitate waste management. A survey of 12 farms in Florida examined bovine manure from lagoons, barns, and screened solids piles for the prevalence of Shiga-toxigenic E. coli by targeting the st $x 1 /$ st $x 2$ and $r f b E$ genes. Out of 518 bovine manure samples from ranches and dairies, $9 \%$ were st $x+$ and $19 \%$ of samples were positive for $r f b E$ [59]. Surrounding soil and water are therefore susceptible to pathogenic E. coli contamination when infected cattle have access to water or watersheds, when barns are cleaned and flushed, during storage of manure in lagoons or piles, or after land application when used as a fertilizer. In Georgia, approximately 5,000 poultry farms comprise the largest sector of the agricultural industry, generating $\$ 4,422,695,768$ in 2017 from broiler production alone. Overall, poultry production in Georgia also produces approximately 2 million tons of waste poultry litter [60,61]. The majority of litter is land applied, and a survey of 165 farmers in South Georgia confirmed that 50.3\% used litter as a fertilizer source. Of these 50.3\%, 65.52\% used litter pulled directly from the house without composting. Application rates of litter varied, but $49.1 \%$ of respondents applied at a rate of $251-499 \mathrm{lbs} / \mathrm{acre}$, with $34.0 \%$ of respondents applying less than $251 \mathrm{lbs} /$ acre and 17.0\% applying more than $499 \mathrm{lbs} /$ acre [62]. As poultry litter and bovine manure are known sources of enteric pathogens, including Salmonella and 
pathogenic E. coli [59,62], runoff from cropland fertilized with or exposed to contaminated litter or manure is a prevalent hazard to irrigation water sources [63].

In 2005, a survey was conducted to address temporal and geographic variation of Salmonella in surface waters in the Little River watershed in southern Georgia [64]. This area is generally flat with meandering streams, with high precipitation during summer months (approximately $120 \mathrm{~cm}$ of rainfall annually) and surrounding cattle and broiler chicken production [65]. Forty-five percent of the area is used for agriculture, $48 \%$ is forested, $13 \%$ is wetlands, and $7 \%$ is urban area [66]. Samples were collected from six stations located in the upstream and downstream parts of the river. Results indicated that $79.2 \%$ of the samples were positive for Salmonella, with the highest concentration in the downstream site and the lowest concentrations in the upstream site. Total precipitation for 3 days preceding each sampling was positively correlated with the prevalence of Salmonella [64]. These data indicate that surface water contamination may have occurred in the area due to an increase in runoff and proximity to livestock facilities, such as poultry houses, as well as the presence of native reptiles and amphibians inhabiting the surrounding wetlands. In another study conducted in the same area, water samples were collected from irrigation ponds (near the intake source), storm runoff from forest, and storm flow from ditches and streams to determine the incidence of Salmonella and E. coli contamination in irrigation ponds on fresh produce farms before and after twelve rain events. Results demonstrated that Salmonella and generic E. coli levels were significantly higher after rainfall events in water samples from the ponds and lower in storm runoff from forests [51]. Also, Salmonella was isolated from $100 \%$ of samples collected from storm flow in streams and ditches, suggesting that recharging streams were the possible source of Salmonella in the irrigation ponds after precipitation instead of runoff from forests [51]. In another study, the concentration of $C$. jejuni were positively correlated to rainfall events with an average prevalence of $58 \%$ in water samples collected from six sites along the Satilla River basin in southeast Georgia [67]. This area is mostly used for agriculture (31\%) and $19 \%$ for other activities (i.e., transportation, urban, golf courses) with $51 \%$ forest. In addition, poultry houses are distributed along this watershed, including $50 \%$ of the influent coming from the wastewater treatment plant near poultry slaughterhouses in the downstream part. Therefore, the high prevalence of $C$. jejuni during the summer could be attributed to an increase in rainfall leading to higher levels of runoff carrying poultry and human waste in water samples [67].

The Suwannee River watershed is considered the largest source of free-flowing freshwater to the Gulf of Mexico with approximately two-thirds of the basin located in South Georgia, while the other one-third is located in north-central Florida [68]. More specifically, the lower part of the basin, located in Florida, is mostly flat with substantial soil erosion from agricultural fields. Rainfall events have been reported to increase the water content of soil profile, leading to frequent water runoff to ditches and streams [68]. This basin is a major production area for brassicas, leafy greens, peppers, squash, tomatoes, and watermelons [68,69]. Therefore, the region is an ideal location to investigate the risks of bacterial contamination to irrigated vegetable production areas [70]. Previous studies have identified a high prevalence of fecal contamination in irrigation ponds in this area [50,69,71,72]. In the upper part of the Suwannee River watershed, three studies investigated the occurrence of $E$. coli O157:H7, Salmonella, and C. jejuni contamination in ten vegetable irrigation ponds and their correlation to rainfall. Overall, all the ponds assessed in the study were positive for E. coli O157:H7 and C. jejuni in water samples collected near the irrigation intake from the ponds at some point over a year, with an average prevalence of $14.6 \%$ and $19.3 \%$ for E. coli O157:H7 and C. jejuni, respectively [50,72]. Most importantly, the prevalence of E. coli O157:H7 and Salmonella were positively correlated to rainfall, while, C. jejuni showed no correlation $[50,69,72]$. Data obtained from the three studies demonstrated that wild animals including deer, birds, hogs, rodents, and various reptiles are constantly present in all the irrigation ponds located within the Suwannee River watershed, and are likely sources of Salmonella, E. coli $\mathrm{O} 157: \mathrm{H7}$, and C. jejuni isolated from this area. This indicates that the geographical location of the ponds plays an important role on the microbiological profile of the water due to surrounding animals that host foodborne pathogens $[50,69,72]$. Seasonal fluctuations in wildlife populations, including bird 
migrations, must also be considered. A Texas research team evaluated cecal contents of three migratory bird species, Brown-Headed Cowbirds (Molothrus ater), Common Grackles (Quiscalus quiscula), and Cattle Egrets (Bubulcus ibis), for four consecutives autumns and found that $3.7 \%$ and $14.9 \%$ of birds carried E. coli O157:H7 and Salmonella, respectively [73]. Migratory patterns should be considered when farms assess their food safety risks.

A northeast Florida surface water study found that fecal coliform concentrations in water samples collected from 20 sites across the Saint Johns River were positively correlated to rainfall events for a period of 2 years [74]. The Saint Johns River has historically been described as having a wide fluctuation of fecal bacteria levels in a heavily urbanized area. Therefore, using bacterial source tracking of fecal coliform isolates, the source of fecal coliform contamination found in water was suggested to come from human waste, especially during periods of increased rainfall in summer months, and from wild animals during the fall [74]. In contrast, two studies conducted across central Florida were unable to provide consistent evidence to correlate rainfall to microbial water quality in surface water $[52,75]$. In the first scenario, Salmonella were isolated from all water samples collected from 18 surface water sites including ponds, canals, rivers, and creeks far from animal agriculture over one year, indicating that the prevalence of Salmonella was possibly not due to runoff from livestock [52]. In the second, rainfall occasionally influenced the prevalence of $E$. coli in water sampled from eight farm ponds during a period of 3 years [75]. These data may suggest that rainfall influences the prevalence of fecal contamination in surface water in several ways, and perhaps other factors such as resuspension of sediments and water dilution also directly affect the microbial concentration [76].

\subsection{Temperature and Seasonality}

Seasonal changes and temperature can also contribute to increased microbial levels in surface water and can be directly influenced by precipitation events [14]. Therefore, evaluating temperature and seasonal variation are important to understand the likelihood of irrigation water contamination in order to establish preventive measures and intervention strategies to ensure the microbial safety of fresh produce.

In a study conducted in the Little River watershed in southern Georgia, temperature was positively correlated to the prevalence of Salmonella with significantly higher concentrations during the summer months, which coincides with higher precipitation events [64]. Similar studies conducted in the upper part of the Suwannee River watershed in southern Georgia indicated a seasonal pattern for E. coli O157:H7 and Salmonella prevalence, with elevated levels in months with higher temperatures [50,69]; while, C. jejuni showed a higher prevalence during the spring compared to other seasons [72]. In these studies, the prevalence of E. coli O157:H7 and Salmonella were positively correlated to temperature, while, the prevalence of $C$. jejuni was negatively correlated $[50,69,72]$. According to the U.S. Department of Agriculture, the optimal growth temperatures for foodborne pathogens are between $21-40{ }^{\circ} \mathrm{C}$, often called the "Danger Zone" [77]. However, previous studies have demonstrated that $C$. jejuni has the potential to survive longer in the water under lower temperatures $[78,79]$, similarly reported by Gu et al. [72]. Contrarily, in another study conducted in southeast Georgia, the prevalence of Campylobacter spp. in samples collected along the Satilla River basin was nearly four times higher during the summer, when average water temperatures were significantly higher, compared to fall and spring [67]. In this case, the high bacteria concentration found during warmer months was possibly mediated by rainfall, runoff or increased animal activity during the summer. Thus, since C. jejuni is considered one of the most commonly reported bacteria that cause GI illnesses worldwide, identifying the environmental pattern for specific geographical location is important to predict the microbial quality of water in order to reduce the impact on the public health. 
Table 2. Summary of microbial contamination in irrigation water sources in the Southeastern U.S.

\begin{tabular}{|c|c|c|c|c|c|c|c|}
\hline Location & Pathogens & $\begin{array}{c}\text { Microbial } \\
\text { Occurrence/Prevalence }\end{array}$ & Microbial Concentration & Water Source & Factor & Year & Ref. \\
\hline Georgia & Salmonella & Overall: $79.2 \%$ (57/72) & Range: $4.96 \mathrm{MPN} / \mathrm{L}$ & $\begin{array}{l}\text { Six stations across } \\
\text { the Little River } \\
\text { watershed }\end{array}$ & $\begin{array}{l}\text { Rainfall, seasonal, } \\
\text { and temperature }\end{array}$ & $\begin{array}{l}\text { Apr. (2005)-Apr. } \\
\qquad(2006)\end{array}$ & [64] \\
\hline Georgia & $\begin{array}{l}\text { Salmonella and } \\
\text { generic E. coli }\end{array}$ & $\begin{array}{l}\text { Salmonella: } 49 \%(52 / 107) \\
\text { E. coli: } 103 / 10598 \%\end{array}$ & $\begin{array}{l}\text { Salmonella: } 0.46 \log \text { MPN/100 mL } \\
\text { E. coli: } 0.61 \log \text { MPN/100 mL }\end{array}$ & $\begin{array}{l}\text { Two irrigation } \\
\text { ponds in the Little } \\
\text { River watershed }\end{array}$ & Rainfall & Jan.-Aug. (2013) & [51] \\
\hline Georgia & Campylobacter spp. & $\begin{array}{l}\text { Overall: } \sim 58 \% \\
\text { Seasonal distribution: } \\
\text { - Summer: } ~ 87 \% \\
\text { - Fall: } 53 \% \\
\text { - Winter: } \sim 60 \% \\
\text { - Spring: } \sim 28 \%\end{array}$ & Average: $45.6 \mathrm{CFU} / \mathrm{mL}$ & $\begin{array}{l}\text { Sites located across } \\
\text { the Satilla River } \\
\text { basin }\end{array}$ & $\begin{array}{l}\text { Rainfall, seasonal, } \\
\text { and temperature }\end{array}$ & $\begin{array}{l}\text { June (2003)-May } \\
\text { (2004) }\end{array}$ & [67] \\
\hline Georgia & Salmonella & Salmonella: $11.9 \%(34 / 284)$ & Salmonella: $0.03 \mathrm{MPN} / 100 \mathrm{~mL}$ & $\begin{array}{l}\text { Two farm ponds } \\
\text { and one well in } \\
\text { southwest Georgia }\end{array}$ & Seasonal & $2012-2013$ & [49] \\
\hline Georgia/Florida & E. coli $\mathrm{O} 157: \mathrm{H7}$ & $\begin{array}{l}\text { Overall: } 14.6 \% \\
\text { - Surface water: } 11.7 \% \\
\text { - Subsurface water: } 17.5 \% \\
\text { Seasonal distribution: } \\
\text { - Summer: } 51.7 \% \\
\text { - Fall: } 31.1 \% \\
\text { - Winter: } 6.9 \% \\
\text { - Spring: } 10.3 \%\end{array}$ & - & $\begin{array}{l}\text { Ten irrigation } \\
\text { ponds in the } \\
\text { Suwannee River } \\
\text { watershed }\end{array}$ & $\begin{array}{l}\text { Rainfall, seasonal, } \\
\text { temperature, and } \\
\text { physicochemical }\end{array}$ & $\begin{array}{l}\text { Mar. (2011)-Feb. } \\
\text { (2012) }\end{array}$ & [50] \\
\hline Georgia/Florida & Salmonella & Overall: $37.4 \%$ & $\begin{array}{l}\text { Average: } 0.29 \mathrm{MPN} / \mathrm{liter} \\
\text { Seasonal distribution: } \\
\text { - Mar.: Lower (0.15 MPN/L) } \\
\text { - Sept.: higher (1.24 MPN/L) }\end{array}$ & $\begin{array}{l}\text { Ten irrigation } \\
\text { ponds in the } \\
\text { Suwannee River } \\
\text { watershed }\end{array}$ & $\begin{array}{l}\text { Rainfall, seasonal, } \\
\text { and temperature }\end{array}$ & $\begin{array}{l}\text { Mar. (2011)-Feb. } \\
\text { (2012) }\end{array}$ & [69] \\
\hline Georgia/Florida & $\begin{array}{l}\text { Campylobacter } \\
\text { jejuni }\end{array}$ & $\begin{array}{l}\text { Overall: } 19.3 \%(54 / 280) \\
\text { Seasonal distribution: } \\
\text { - Summer: } 10 \% \\
\text { - Fall: } 13.3 \% \\
\text { - Winter: } 10 \% \\
\text { - Spring: } 50 \%\end{array}$ & - & $\begin{array}{l}\text { Ten irrigation } \\
\text { ponds in the } \\
\text { Suwannee River } \\
\text { watershed }\end{array}$ & $\begin{array}{l}\text { Rainfall, seasonal, } \\
\text { temperature, and } \\
\text { physicochemical }\end{array}$ & $\begin{array}{l}\text { Jan. (2011)-Feb. } \\
\qquad(2012)\end{array}$ & [72] \\
\hline
\end{tabular}


Table 2. Cont

\begin{tabular}{|c|c|c|c|c|c|c|c|}
\hline Location & Pathogens & $\begin{array}{c}\text { Microbial } \\
\text { Occurrence/Prevalence }\end{array}$ & Microbial Concentration & Water Source & Factor & Year & Ref. \\
\hline Georgia/Florida & Salmonella & Overall: $29.4 \%(50 / 170)$ & - & $\begin{array}{l}\text { Ten irrigation } \\
\text { ponds in the } \\
\text { Suwannee River } \\
\text { watershed }\end{array}$ & Seasonal & $\begin{array}{l}\text { July (2011)-Sep. } \\
\text { (2013) }\end{array}$ & [80] \\
\hline Florida & Fecal coliforms & - & Average: $26.24 \mathrm{CFU} / 100 \mathrm{~mL}$ & $\begin{array}{l}\text { Seven sites across } \\
\text { the Saint. Johns } \\
\text { River }\end{array}$ & $\begin{array}{l}\text { Rainfall, seasonal, } \\
\text { and bacteria } \\
\text { source }\end{array}$ & $\begin{array}{l}\text { Dec. (2000)-July } \\
\text { (2002) }\end{array}$ & [74] \\
\hline Florida & $\begin{array}{l}\text { Salmonella and } E \text {. } \\
\text { coli }\end{array}$ & $\begin{array}{l}\text { Salmonella: } 4.8 \% \\
\text { STEC: } 2.6 \%\end{array}$ & $\begin{array}{l}\text { Range: } \\
\text { Generic } \text { E. coli: from } 0 \text { to } 4.2 \log \\
\text { MPN/100 mL }\end{array}$ & $\begin{array}{l}\text { Six farm ponds in } \\
\text { west central } \\
\text { Florida }\end{array}$ & $\begin{array}{l}\text { Rainfall, and } \\
\text { bacteria source }\end{array}$ & 2012-2015 & [75] \\
\hline Florida & $\begin{array}{l}\text { Salmonella and } E \text {. } \\
\text { coli }\end{array}$ & - & $\begin{array}{l}\text { Salmonella: } 0.79 \log \mathrm{MPN} / 100 \mathrm{~mL} \\
\text { E. coli: } 1.7 \log \mathrm{MPN} / 100 \mathrm{~mL}\end{array}$ & $\begin{array}{l}\text { Surface water in } \\
\text { the area of central } \\
\text { Florida }\end{array}$ & $\begin{array}{l}\text { Rainfall, seasonal, } \\
\text { and temperature }\end{array}$ & $\begin{array}{l}\text { Aug. (2010)-July } \\
\text { (2011) }\end{array}$ & [52] \\
\hline Tennessee & Fecal coliforms & - & - & $\begin{array}{l}\text { Sites located along } \\
\text { the Little River }\end{array}$ & Seasonal & $\begin{array}{l}\text { Oct. (2000)-Dec. } \\
\text { (2005) }\end{array}$ & [81] \\
\hline
\end{tabular}


In a survey conducted in the Suwannee River watershed, the overall prevalence of Salmonella spp. was $29.4 \%$ during a 2-year period, with a higher prevalence in the summer months compared to the other seasons in water samples collected near the intake source from 10 irrigation ponds [80]. Contrarily, in another 1-year study conducted in the same area, Salmonella was mostly found in water samples during the fall season $(15.3 \%)$ when compared to spring $(10.3 \%)$, summer $(9.1 \%)$, and winter $(0.0 \%)$; with a likelihood of an increase in Salmonella concentration by 3.7 times with a raise in the water temperature within the range of $17-25^{\circ} \mathrm{C}$ [49]. These results demonstrate that the direct comparison of temperature and seasonality with the prevalence of pathogens is very complex and may rely on other factors such as geographical location, water source, time of sampling, and method of bacteria identification. In this case, $\mathrm{Li}$ et al. [80] used a newly developed qPCR (quantitative polymerase chain reaction) to improve Salmonella detection from environmental waters, proven to have higher sensitivity than the conventional culture-based method used by Antaki et al. [49]. Therefore, discrepancies from these studies conducted at the same area may have occurred due to sensitivity of the identification method.

In a survey conducted across the Saint Johns River in Florida, the prevalence of fecal coliforms in surface water was increased during the summer season, especially in July [74]. Contrarily, the prevalence of Salmonella in water samples collected from several surface water sources including ponds, canals, rivers, and creeks throughout central Florida during a 1-year study was not influenced by seasonal variation [52]. Particularly in this case, the variability of the water sources used for sampling may have impacted the lack of correlation between the prevalence of Salmonella and seasonality [52].

In a 5-year study conducted in the Little River in east Tennessee, total coliform concentrations were higher in summer months and lower in winter months, seemingly related to the temperature [81]. This area is generally composed of forestland and mixed-use (agriculture and urban development), which could contribute to the recurrent bacterial contamination of this water source as previously reported $[82,83]$. Similarly, results from a 5-year survey found that the prevalence of $E$. coli in water samples collected along Browns, Richland and Mill watersheds in Tennessee were significantly higher in the summer and spring and lower in the fall and winter [84]. However, these three watersheds are listed on the 303(d) list as impaired due to high levels of E. coli, making their use for agriculture inappropriate [85].

\subsection{Water Physicochemical Properties}

Water physicochemical properties, such as turbidity, water $\mathrm{pH}$, oxidation-reduction potential, as well as concentrations of nitrate, chlorine, and phosphate, may impact microbial populations in surface water $[50,86]$. The survival of pathogenic microorganisms can also be impacted by factors such as microbial competition, organic matter, and solar radiation [50]. For instance, phosphate seems to increase the survival rate of foodborne pathogens, such as E. coli, Salmonella and Campylobacter spp. $[78,87,88]$, while sunlight exposure has been shown to reduce the survival of E. coli, Shigella flexneri and Vibrio cholera, more so than Salmonella serotype Typhimurium [89]. Conductivity, which corresponds to the number of dissolved solids and salinity, may also influence bacterial concentrations. Results from a study conducted in central Florida showed that turbidity, oxidation-reduction potential, and conductivity predicted the presence of Salmonella in water [52]. Likewise, other studies have reported that Salmonella prevalence is highly influenced by water conductivity and oxygen concentrations in fresh water $[90,91]$. The study also found that Salmonella was positively correlated to solar radiation, which is in agreement with the previously described study and indicates that Salmonella may be more resistant to solar radiation than other pathogenic bacteria [52].

Data from two surveys conducted across the Suwannee River watershed in southern Georgia showed that the prevalence of E. coli O157:H7 was negatively correlated to total nitrogen and nitrate concentrations in water samples collected from irrigation ponds, while C. jejuni was found to be positively correlated to nitrate and total nitrogen [50,72]. These results suggest that variation in nitrogen levels in the water can affect the microbial diversity of the water source, e.g., when nitrogen levels rise 
in the water, C. jejuni is more likely to survive than E. coli O157:H7, and when nitrogen levels fall, $E$. coli O157:H7 will prevail. It is important to highlight that this implication is potentiated during the summer, when rainfall events are more frequent and after heavy rainfall when soil water runoff occurs. Therefore, limiting nitrogen content in these irrigation ponds, especially in high precipitation months, is a suggested strategy to reduce the risks of crop contamination with $C$. jejuni during irrigation events.

However, the relationship between water physicochemical properties is also highly dependent on the seasonality and geographical location of the water sources [92], and the complexity of the correlation between these factors and the prevalence of pathogenic microorganisms in water has been inadequately investigated in the Southeastern U.S.

\section{Strategies to Reduce Microbial Load in Agricultural Water Sources}

Several strategies are available to reduce the microbial load in irrigation water sources, including chemical treatments, antimicrobial devices and physical (sand or screen) filtration. Chlorine, in the form of calcium or sodium hypochlorite, is the most frequently utilized antimicrobial treatment (chemical or device) used to control microorganisms due to its low cost and efficacy; however, chlorine requires continuous monitoring as excess chlorine can be a public and worker health hazard [14], and because levels as low as $2.5 \mathrm{ppm}$ free chlorine can result in phytotoxicity and decreased biomass in plants [93,94]. Suggested dosage rates for surface water sources range from 5 to $10 \mathrm{ppm}$ with recommended residual rates at the furthest point in the irrigation system around 1 to $2 \mathrm{ppm}$ to ensure antimicrobial treatment occurs throughout the entire system [95]. Organic matter has a deleterious impact on chlorine treatments as it binds with free chlorine, reducing its antimicrobial efficacy. For this reason, water from turbid sources may require filtration prior to chlorination, resulting in additional expense, monitoring, and maintenance. The use of peroxyacetic acid as a sustainable strategy to treat water has gained increased attention, and it has shown to be a suitable substitute for chlorination. Peroxyacetic acid is not as sensitive to the presence of organic matter as chlorine; additionally, unlike chlorine which produces toxic by-products including trihalomethanes and haloacetic acids, the degradation end products of peroxyacetic acid are non-toxic and include acetic acid, hydrogen peroxide, water, and oxygen [96,97]. However, the higher cost of peroxyacetic acid due to its limited production worldwide restricts many growers' ability to adopt this chemical treatment [98].

Ultraviolet (UV-C) radiation treatment has been shown to be highly effective against bacteria in irrigation water, but its efficacy can be influenced by turbidity and organic matter in the water, and the initial costs associated with implementing these systems are still a barrier for some growers [99]. Additionally, unlike chemical sanitizers, once water passes the UV-C bulb, no downstream or residual antimicrobial activity occurs. While this may be advantageous for plant physiology, the remainder of the irrigation system does not receive any bactericidal or fungicidal treatment, which may facilitate the colonization of plant or foodborne pathogens within the irrigation lines, or clogged emitters as microbial bioaccumulation occurs.

\section{Conclusions}

Surface water is a primary source of production water for fruit and vegetable growers throughout the U.S. However, the microbial quality of surface water used for agriculture is variable, and contaminated water can introduce foodborne pathogens to fresh produce. Environmental factors, geographical location, surrounding land use, proximity to livestock operations, wildlife, and water physicochemical properties considerably impact the microbial quality of surface waters. Overall, in the Southeastern U.S. the prevalence of foodborne pathogens has been shown to be elevated during rainfall events, mostly due to runoff, as well as during the spring and summer seasons when higher temperatures favor microbial growth. However, some studies indicate that some bacteria like $C$. jejuni are more prevalent during the colder months, when cooler temperatures appear to facilitate their survival. These disparities highlight the importance of identifying multiple suitable indicators to monitor water quality, especially during the spring and fall when most of the produce is grown in 
the Southeastern U.S. Additionally, the impact of water physicochemical properties on the prevalence of foodborne pathogens appears to be microorganism specific, indicating a need for further research to elucidate efficacious physicochemical indicators. Research focused on the factors impacting the microbial quality of irrigation water in the Southeastern U.S. is relatively limited. More information is necessary to decisively identify factors that affect the prevalence of foodborne pathogens in agricultural water sources, and how these factors may serve to predict the likelihood of pathogen contamination.

Author Contributions: Original Draft Preparation, C.R., A.L.B.R.d.S., and L.L.D.; Review \& Editing, L.L.D. All authors have read and agreed to the published version of the manuscript.

Funding: This research received no external funding.

Conflicts of Interest: The authors declare no conflict of interest.

\section{References}

1. CDC. Estimates of Foodborne Illness in the United States. Available online: https://www.cdc.gov/ foodborneburden/2011-foodborne-estimates.html (accessed on 5 November 2018).

2. Scallan, E.; Hoekstra, R.M.; Angulo, F.J; Tauxe, R.V.; Widdowson, M.A.; Roy, S.L.; Jones, J.L.; Griffin, P.M. Foodborne illness acquired in the United States-major pathogens. Emerg. Infect. Dis. 2011, 17, 7-15. [CrossRef] [PubMed]

3. CDC. Outbreak of Salmonella Serotype Saintpaul Infections Associated with Multiple Raw Produce Items-United States, 2008. Morb. Mortal. Wkly. Rep. 2008, 57, 929-934.

4. CDC. Multistate Outbreak of Human Salmonella I 4, [5],12: i: -Infections Linked to Alfalfa Sprouts (Final Update). Available online: https://www.cdc.gov/salmonella/2010/alfalfa-sprouts-2-10-11.html (accessed on 10 February 2011).

5. Greene, S.K.; Daly, E.R.; Talbot, E.A.; Demma, L.J.; Holzbauer, S.; Patel, N.J.; Hill, T.A.; Walderhaug, M.O.; Hoekstra, R.M.; Lynch, M.F.; et al. Recurrent multistate outbreak of Salmonella Newport associated with tomatoes from contaminated fields, 2005. Epidemiol. Infect. 2008, 136, 157-165. [CrossRef] [PubMed]

6. Soderstrom, A.; Osterberg, P.; Lindqvist, A.; Jonsson, B.; Blide, U.S.; Welinder-Olsson, C.; Lofdahl, S.; Kaijser, B.; De Jong, B.; Kuhlmann-Berenzon, S.; et al. A large Escherichia coli O157 outbreak in Sweden associated with locally produced lettuce. Foodborne Pathog. Dis. 2008, 5, 339-349. [CrossRef]

7. CDC. Outbreak of E. coli Infections Linked to Romaine Lettuce: Final Update. Available online: https://www.cdc.gov/ecoli/2018/o157h7-11-18/index.html (accessed on 1 November 2019).

8. FDA. Adam Bros. Farming, Inc. Recalls Red and Green Leaf Lettuce and Cauliflower Because of Possible Health Risk. Available online: https://www.fda.gov/safety/recalls-market-withdrawals-safety-alerts/adambros-farming-inc-recalls-red-and-green-leaf-lettuce-and-cauliflower-because-possible-health (accessed on 17 December 2018).

9. Hussain, M.A.; Gooneratne, R. Understanding the Fresh Produce Safety Challenges. Foods 2017, 6, 23. [CrossRef]

10. Hussain, M.A.; Dawson, C.O. Economic Impact of Food Safety Outbreaks on Food Businesses. Foods 2013, 2, 585-589. [CrossRef]

11. FDA. Food Safety Modernization Act: Standards for the Growing, Harvesting, Packing, and Holding of Produce for Human Consumption, Proposed Rule, 2013 (Docket No. FDA-2011-N-0921); Food and Drug Administration: Washington, DC, USA, 2013.

12. Godfray, H.C.; Beddington, J.R.; Crute, I.R.; Haddad, L.; Lawrence, D.; Muir, J.F.; Pretty, J.; Robinson, S.; Tomas, S.M.; Toulmin, C. Food security: The challenge of feeding 9 billion people. Science 2010, 327, 812-818. [CrossRef]

13. Pandey, P.K.; Kass, P.H.; Soupir, M.L.; Biswas, S.; Singh, V.P. Contamination of water resources by pathogenic bacteria. AMB Express 2014, 4, 51. [CrossRef]

14. Gil, M.I.; Selma, M.V.; Suslow, T.; Jacxsens, L.; Uyttendaele, M.; Allende, A. Pre-and postharvest preventive measures and intervention strategies to control microbial food safety hazards of fresh leafy vegetables. Crit. Rev. Food Sci. Nutr. 2015, 55, 453-468. [CrossRef]

15. Steele, M.; Odumeru, J. Irrigation water as source of foodborne pathogens on fruit and vegetables. J. Food Prot. 2004, 67, 2839-2849. [CrossRef] 
16. Köppen, W.P. Grundriss der Klimakunde; Walter de Gruyter: Berlin, Germany, 1931.

17. Ritschard, R.L.; Cruise, J.F.; Hatch, L.U. Spatial and temporal analysis of agricultural water requirements in the gulf coast of the united states. J. Am. Water Resour. Assoc. 1999, 35, 1585-1596. [CrossRef]

18. Fereres, E.; Goldhamer, D.A.; Parsons, L.R. Irrigation water management of horticultural crops. Hort Sci. 2003, 38, 1036-1042. [CrossRef]

19. Mullen, J.D.; Yu, Y.; Hoogenboom, G. Estimating the demand for irrigation water in a humid climate: A case study from the southeastern United States. Agric. Water Manag. 2009, 96, 1421-1428. [CrossRef]

20. da Silva, A.L.B.R.; Coolong, T. Advances in irrigation techniques in vegetable cultivation. In Achieving Sustainable Cultivation of Vegetables; Hochmuth, G., Dodds, B., Eds.; Science Publishing: London, UK, 2019; pp. 121-137.

21. Stine, S.W.; Song, I.; Choi, C.Y.; Gerba, C.P. Effect of relative humidity on preharvest survival of bacterial and viral pathogens on the surface of cantaloupe, lettuce, and bell peppers. J. Food Prot. 2005, 68, 1352-1358. [CrossRef] [PubMed]

22. Stine, S.W.; Song, I.; Choi, C.Y.; Gerba, C.P. Application of microbial risk assessment to the development of standards for enteric pathogens in water used to irrigate fresh produce. J. Food Prot. 2005, 68, 913-918. [CrossRef]

23. Marites, M.; Tiongco, C.A.; Bidwell, K. Risk analysis integrating livelihood and economic impacts of wastewater irrigation on health. In Wastewater Irrigation and Health; Raschid-Sally, L., Redwood, M., Bahri, A., Drechsel, P., Eds.; The International Development Research Centre (IDRC): Scott, CA, Canada, 2010; Earthscan/IDRC 2010.

24. Allende, A.; Castro-Ibáñez, I.; Lindqvist, R.; Gil, M.I.; Uyttendaele, M.; Jacxsens, L. Quantitative contamination assessment of Escherichia coli in baby spinach primary production in Spain: Effects of weather conditions and agricultural practices. Int. J. Food Microbiol 2017, 257, 238-246. [CrossRef]

25. da Silva, A.L.B.R.; Hashiguti, H.T.; Zotarelli, L.; Migliaccio, K.W.; Dukes, M.D. Soil Water Dynamics of Shallow Water Table Soils Cultivated With Potato Crop. Vadose Zone J. 2018, 17, 15.

26. Qadir, M. Sustainable Management of Wastewater for agriculture. In Proceedings of the First Bridging Workshop, International Center for Agricultural Research in the Dry Areas (ICARDA), Aleppo, Syria, 11-15 November 2007; pp. 11-15.

27. Rochelle-Newall, E.; Nguyen, T.M.; Le, T.P.; Sengtaheuanghoung, O.; Ribolzi, O. A short review of fecal indicator bacteria in tropical aquatic ecosystems: Knowledge gaps and future directions. Front. Microbiol. 2015, 6, 308. [CrossRef]

28. USDA. National Agricultural Statistics Service. 2017. Available online: https://www.nass.usda.gov/ (accessed on 2 November 2019).

29. Berndt, M.P.; Katz, B.G.; Kingsbury, J.A.; Crandall, C.A. The quality of our Nation's waters-Water quality in the Upper Floridan aquifer and overlying surficial aquifers, southeastern United States, 1993-2010: U.S. Geol. Surv. Circ. 2014, 1355, 72.

30. Rock, C.M.; Brassill, N.; Dery, J.L.; Carr, D.; McLain, J.E.; Bright, K.R.; Gerba, C.P. Review of water quality criteria for water reuse and risk-based implications for irrigated produce under the FDA Food Safety Modernization Act, produce safety rule. Environ. Res. 2019, 172, 616-629. [CrossRef]

31. Lawrence, R.P.; Sheikh, B.; Holden, R.; York, D.W. Reclaimed Water as an Alternative Water Source for Crop Irrigation. HortScience 2010, 45, 1626-1629.

32. Ferguson, C.; Husman, A.M.R.; Altavilla, N.; Deere, D.; Ashbolt, N. Fate and Transport of Surface Water Pathogens in Watersheds. Crit. Rev. Environ. Sci. Technol. 2003, 33, 299-361. [CrossRef]

33. Uyttendaele, M.; Jaykus, L.A.; Amoah, P.; Chiodini, A.; Cunliffe, D.; Jacxsens, L. Microbial Hazards in Irrigation Water: Standards, Norms, and Testing to Manage Use of Water in Fresh Produce Primary Production. Compr. Rev. Food Sci. Food Saf. 2015, 14, 336-356. [CrossRef]

34. FDA. Title 21 of the Code of Federal Regulations, Proposed Part 112-Standards for the Growing, Harvesting, Packing, and Holding of Produce for Human Consumption, Tracked Changes Compared to Proposed Part 112 Issued on January 16, 2013. Available online: https://www.federalregister.gov/documents/2015/11/27/201528159/standards-for-the-growing-harvesting-packing-and-holding-of-produce-for-human-consumption (accessed on 27 November 2019). 
35. FDA. Title 21 of the Code of Federal Regulations, Final Rule Part 112—Standards for the Growing, Harvesting, Packing, and Holding of Produce for Human Consumption, Extension of Compliance Dates for Subpart, E. Available online: https://www.federalregister.gov/documents/2019/03/18/2019-04652/standards-for-thegrowing-harvesting-packing-and-holding-of-produce-for-human-consumption-extension (accessed on 18 March 2019).

36. Deering, A.J.; Jack, D.R.; Pruitt, R.E.; Mauer, L.J. Movement of Salmonella serovar Typhimurium and E. coli O157:H7 to Ripe Tomato Fruit Following Various Routes of Contamination. Microorganisms 2015, 3, 809-825. [CrossRef] [PubMed]

37. CDC. Multistate Outbreak of Salmonella Typhimurium Infections Linked to Tomatoes (FINAL UPDATE). Available online: https://www.cdc.gov/salmonella/2006/tomatoes-11-2006.html (accessed on 3 November 2006).

38. CDC. Multistate Outbreak of Salmonella Saintpaul Infections Linked to Raw Produce (FINAL UPDATE). Available online: https://www.cdc.gov/salmonella/2008/raw-produce-8-28-2008.html (accessed on 28 August 2008).

39. Barak, J.D.; Liang, A.; Narm, K.E. Differential Attachment to and Subsequent Contamination of Agricultural Crops by Salmonella enterica. Appl. Environ. Microbiol. 2008, 74, 5568-5570. [CrossRef]

40. CDC. Outbreak of E. coli Infections Linked to Romaine Lettuce Final Update. Available online: https://www.cdc.gov/ecoli/2019/o157h7-11-19/index.html (accessed on 4 December 2019).

41. FDA. Outbreak Investigation of E. coli O157:H7 Linked to Romaine Lettuce Grown in CA. Available online: fda.gov/food/outbreaks-foodborne-illness/outbreak-investigation-e-coli-o157h7-linkedromaine-lettuce-grown-ca (accessed on 13 February 2019).

42. CDC. Multistate Outbreak of Shiga toxin-producing Escherichia coli O157:H7 Infections Linked to Leafy Greens (Final Update). Available online: https://www.cdc.gov/ecoli/2017/o157h7-12-17/index.html (accessed on 25 January 2018).

43. CDC. Multistate Outbreak of Shiga Toxin-producing Escherichia coli O157:H7 Infections Linked to Organic Spinach and Spring Mix Blend (Final Update). Available online: https://www.cdc.gov/ecoli/2012/o157h7-1112/index.html (accessed on 10 December 2012).

44. CDC. Multistate Outbreak of E. coli O157:H7 Infections Linked to Romaine Lettuce (FINAL UPDATE). Available online: https://www.cdc.gov/ecoli/2018/o157h7-04-18/index.html (accessed on 28 June 2018).

45. CDC. Multistate Outbreak of Human, E. coli O145 Infections Linked to Shredded Romaine Lettuce from a Single Processing Facility (FINAL UPDATE). Available online: https://www.cdc.gov/ecoli/2010/shreddedromaine-5-21-10.html (accessed on 21 May 2010).

46. CDC. Multistate Outbreak of E. coli O157:H7 Infections Linked to Fresh Spinach (FINAL UPDATE). Available online: https://www.cdc.gov/ecoli/2006/spinach-10-2006.html (accessed on 6 October 2006).

47. Patel, J.; Sharma, M. Differences in attachment of Salmonella enterica serovars to cabbage and lettuce leaves. Int. J. Food Microbiol. 2010, 139, 41-47. [CrossRef]

48. FDA. How Did FDA Establish Requirements for Water Quality and Testing of Irrigation Water under the FSMA Final Rule for Produce Safety. Available online: https://www.fda.gov/food/food-safety-modernizationact-fsma/how-did-fda-establish-requirements-water-quality-and-testing-irrigation-water-under-fsmafinal-rule (accessed on 20 November 2017).

49. Antaki, E.M.; Vellidis, G.; Harris, C.; Aminabadi, P.; Levy, K.; Jay-Russell, M.T. Low Concentration of Salmonella enterica and Generic Escherichia coli in Farm Ponds and Irrigation Distribution Systems Used for Mixed Produce Production in Southern Georgia. Foodborne Pathog. Dis. 2016, 13, 551-558. [CrossRef]

50. Gu, G.; Luo, Z.; Cevallos-Cevallos, J.M.; Adams, P.; Vellidis, G.; Wright, A.; van Bruggen, A.H. Factors affecting the occurrence of Escherichia coli $\mathrm{O} 157$ contamination in irrigation ponds on produce farms in the Suwannee River Watershed. Can. J. Microbiol. 2013, 59, 175-182. [CrossRef]

51. Harris, C.S.; Tertuliano, M.; Rajeev, S.; Vellidis, G.; Levy, K. Impact of storm runoff on Salmonella and Escherichia coli prevalence in irrigation ponds of fresh produce farms in southern Georgia. J. Appl. Microbiol. 2018, 124, 910-921. [CrossRef]

52. McEgan, R.; Moolian, G.; Goodridge, L.D.; Schaffner, D.W.; Danyluk, M.D. Predicting Salmonella populations from biological, chemical, and physical indicators in Florida surface waters. Appl. Environ. Microbiol. 2013, 79, 4094-4105. [CrossRef] 
53. Benjamin, L.; Atwill, E.R.; Jay-Russel, M.; Cooley, M.; Carychao, D.; Gorski, L.; Mandrell, R.E. Occurrence of generic Escherichia coli, E. coli $\mathrm{O} 157$ and Salmonella spp. in water and sediment from leafy green produce farms and streams on the Central California coast. Int. J. Food Microbiol. 2013, 165, 65-76. [CrossRef] [PubMed]

54. Horman, A.; Rimhanen-Finne, R.; Maunula, L.; von Bonsdorff, C.H.; Torvela, N.; Heikinheimo, A.; Hänninen, M.L. Campylobacter spp., Giardia spp., Cryptosporidium spp., noroviruses, and indicator organisms in surface water in southwestern Finland, 2000-2001. Appl. Environ. Microbiol. 2004, 70, 87-95. [CrossRef] [PubMed]

55. Cooley, M.; Carychao, D.; Crawford-Miksza, L.; Jay, M.T.; Myers, C.; Rose, C.; Keys, C.; Farrar, J.; Mandrell, R.E. Incidence and tracking of Escherichia coli O157:H7 in a major produce production region in California. PLoS ONE 2007, 2, e1159. [CrossRef] [PubMed]

56. Ishii, S.; Sadowsky, M.J. Es cherichia coli in the Environment: Implications for Water Quality and Human Health. Microbes Environ. 2008, 23, 101-108. [CrossRef]

57. Ewing, J.J. Virtual water: Tackling the threat to our planet's most precious resource, by Tony Allen. Water Int. 2011, 36, 948-950. [CrossRef]

58. Johannessen, G.S.; Wennberg, A.C.; Nesheim, I.; Tryland, I. Diverse Land Use and the Impact on (Irrigation) Water Quality and Need for Measures-A Case Study of a Norwegian River. Int. J. Environ. Res. Public Health 2015, 12, 6979-7001. [CrossRef]

59. Baker, C.A.; De, J.; Bertoldi, B.; Dunn, L.; Chapin, T.; Jay-Russell, M.; Danyluk, M.D.; Schneider, K.R. Prevalence and concentration of stx + E. coli and E. coli $\mathrm{O} 157$ in bovine manure from Florida farms. PLoS ONE 2019, 14, e0217445. [CrossRef]

60. Wolfe, K.; Stubbs, K. 2017 Georgia Farm Gate Value Report; University of Georgia College of Agricultural and Environmental Sciences Center for Agribusiness and Economic Development: Athens, GA, USA, 2018; AR-18-01.

61. Dunkley, C.S.; Cunningham, D.L.; Harris, G.H. The value of poultry litter in south Georgia. UGA Coop. Ext. Bull 2011, 1386, 7.

62. Bhatia, T.R.; McNabb, G.D. Dissemination of Salmonella in broiler-chicken operations. Avian Dis. 1980, 24, 616-624. [CrossRef]

63. Bolan, N.S.; Szogi, A.A.; Chuasavathi, T.; Seshadri, B.; Rothrock, M.J.; Panneerselvam, P. Uses and management of poultry litter. World's Poult. Sci. J. 2010, 66, 673-698. [CrossRef]

64. Haley, B.J.; Cole, D.J.; Lipp, E.K. Distribution, diversity, and seasonality of waterborne salmonellae in a rural watershed. Appl. Environ. Microbiol. 2009, 75, 1248-1255. [CrossRef] [PubMed]

65. Bosch, D.D.; Lowrance, R.R.; Sheridan, J.M.; Williams, R.G. Ground Water Storage Effect on Streamflow for a Southeastern Coastal Plain Watershed. Groundwater 2003, 41, 903-912. [CrossRef]

66. USGS. Land Cover, Elevation, Hydrography, and Imagerydatasets. Available online: https://nationalmap.gov (accessed on 27 November 2014).

67. Vereen, E., Jr.; Lowrance, R.R.; Cole, D.J.; Lipp, E.K. Distribution and ecology of campylobacters in coastal plain streams (Georgia, United States of America). Appl. Environ. Microbiol. 2007, 73, 1395-1403. [CrossRef] [PubMed]

68. Obreza, T.; Means, G. Characterizing Agriculture in Florida's Lower Suwannee River Basin Area; Soil and Water Science Department, Florida Cooperative Extension Service, Institute of Food and Agricultural Sciences, University of Florida: Gainesville, FL, USA, 2006; pp. 1-15.

69. Luo, Z.; Gu, G.; Ginn, A.; Giurcanu, M.C.; Adams, P.; Vellidis, G.; van Bruggen, A.H.; Danyluk, M.D.; Wright, A.C. Distribution and Characterization of Salmonella enterica Isolates from Irrigation Ponds in the Southeastern United States. Appl. Environ. Microbiol. 2015, 81, 4376-4387. [CrossRef]

70. Davis, M.M.; Hicks, D.W. Water resources of the upper suwannee river watershed. Proc. Ga. Water Resour. Conf. 2001, 70-74.

71. Rajabi, M.; Jones, M.; Hubbard, M.; Rodrick, G.; Wright, A.C. Distribution and Genetic Diversity of Salmonella enterica in the Upper Suwannee River. Int. J. Microbiol. 2011, 2011, 9. [CrossRef]

72. Gu, G.; Luo, Z.; Cevallos-Cevallos, J.M.; Adams, P.; Vellidis, G.; Wright, A.; van Bruggen, A.H. Occurrence and population density of Campylobacter jejuni in irrigation ponds on produce farms in the Suwannee River Watershed. Can. J. Microbiol. 2013, 59, 339-346. [CrossRef] 
73. Callaway, T.R.; Edrington, T.S.; Nisbet, D.J. Isolation of Escherichia coli O157:H7 and Salmonella from migratory brown-headed cowbirds (Molothrus ater), common Grackles (Quiscalus quiscula), and cattle egrets (Bubulcus ibis). Foodborne Pathog Dis. 2014, 11, 791-794. [CrossRef]

74. Shehane, S.D.; Harwood, V.J.; Whitlock, J.E.; Rose, J.B. The influence of rainfall on the incidence of microbial faecal indicators and the dominant sources of faecal pollution in a Florida river. J. Appl. Microbiol. 2005, 98, 1127-1136. [CrossRef]

75. Topalcengiz, Z.; Strawn, L.K.; Danyluk, M.D. Microbial quality of agricultural water in Central Florida. PLOS ONE 2017, 12, e0174889. [CrossRef]

76. Santiago-Rodriguez, T.M.; Tremblay, R.L.; Toledo-Hernandez, C.; Gonzalez-Nieves, J.E.; Ryu, H.; Domingo, J.W.S.; Toranzos, G.A. Microbial quality of tropical inland waters and effects of rainfall events. Appl. Environ. Microbiol. 2012, 78, 5160-5169. [CrossRef] [PubMed]

77. USDA. “Danger Zone" ( $\left.40^{\circ} \mathrm{F}-140^{\circ} \mathrm{F}\right)$. Available online: https://www.fsis.usda.gov/wps/portal/fsis/topics/ food-safety-education/get-answers/food-safety-fact-sheets/safe-food-handling/danger-zone-40-f-140-f/ CT_Index (accessed on 28 June 2017).

78. Buswell, C.M.; Herlihy, Y.M.; Lawrence, L.M.; McGuiggan, J.T.M.; Marsh, P.D.; Keevil, C.W.; Leach, S.A. Extended survival and persistence of Campylobacter spp. in water and aquatic biofilms and their detection by immunofluorescent-antibody and -rRNA staining. Appl. Environ. Microbiol. 1998, 64, 733-741. [CrossRef] [PubMed]

79. Terzieva, S.I.; McFeters, G.A. Survival and injury of Escherichia coli, Campylobacter jejuni, and Yersinia enterocolitica in stream water. Can. J. Microbiol. 1991, 37, 785-790. [CrossRef] [PubMed]

80. Li, B.; Vellidis, G.; Liu, H.; Jay-Russell, M.; Zhao, S.; Hu, Z.; Wright, A.; Elkins, C.A. Diversity and antimicrobial resistance of Salmonella enterica isolates from surface water in Southeastern United States. Appl. Environ. Microbiol. 2014, 80, 6355-6365. [CrossRef]

81. Koirala, S.R.; Gentry, R.W.; Perfect, E.; Schwartz, J.S.; Sayler, G.S. Temporal variation and persistence of bacteria in streams. J. Environ. Qual. 2008, 37, 1559-1566. [CrossRef]

82. Gentry, R.W.; McCarthy, J.; Layton, A.; McKay, L.D.; Williams, D.; Koirala, S.R.; Sayler, G.S. Escherichia coli loading at or near base flow in a mixed-use watershed. J. Environ. Qual. 2006, 35, 2244-2249. [CrossRef]

83. Gentry, R.W.; Layton, A.C.; McKay, L.D.; McCarthy, J.F.; Williams, D.E.; Koirala, S.R.; Sayler, G.S. Efficacy of Bacteroides measurements for reducing the statistical uncertainty associated with hydrologic flow and fecal loads in a mixed use watershed. J. Environ. Qual. 2007, 36, 1324-1330. [CrossRef]

84. Stallard, M.A.; Otter, R.R.; Winesett, S.; Barbero, M.; Bruce, M.; Layton, A.; Bailey, F.C. A Watershed Analysis of Seasonal Concentration- and Loading-based Results for Escherichia coli in Inland Waters. Bull. Environ. Contam. Toxicol. 2016, 97, 838-842. [CrossRef]

85. TDEC. Draft Version Year 2016 303(d) List; Tennessee Department of Environment and Conservation, Planning and Standards Unit Division of Water Resources: Nashville, TN, USA, 2016.

86. Chigor, V.N.; Umoh, V.J.; Smith, S.I. Occurrence of Escherichia coli O157 in a river used for fresh produce irrigation in Nigeria. Afr. J. Biotechnol. 2010, 9, 178-182.

87. Li, J.; Ding, M.; Han, Z.; Ma, J. Persistence of Salmonella Typhimurium in Well Waters from a Rural Area of Changchun City, China. Int. J. Environ. Res. Public Health 2018, 15, 1090. [CrossRef]

88. Juhna, T.; Birzniece, D.; Rubulis, J. Effect of Phosphorus on Survival of Escherichia coli in Drinking Water Biofilms. Appl. Environ. Microbiol. 2007, 73, 3755. [CrossRef] [PubMed]

89. Berney, M.; Weilenmann, H.U.; Simonetti, A.; Egli, T. Efficacy of solar disinfection of Escherichia coli, Shigella flexneri, Salmonella Typhimurium and Vibrio cholerae. J. Appl. Microbiol. 2006, 101, 828-836. [CrossRef] [PubMed]

90. Mugnai, R.; Sattamini, A.; Santos, J.A.A.; Regua-Mangia, A.H. A Survey of Escherichia coli and Salmonella in the Hyporheic Zone of a Subtropical Stream: Their Bacteriological, Physicochemical and Environmental Relationships. PLoS ONE 2015, 10, e0129382. [CrossRef] [PubMed]

91. Jiménez, L.; Muñiz, I.; Toranzos, G.A.; Hazen, T.C. Survival and activity of Salmonella typhimurium and Escherichia coli in tropical freshwater. J. Appl. Bacteriol. 1989, 67, 61-69. [CrossRef] [PubMed]

92. Lenart-Boroń, A.; Wolanin, A.A.; Jelonkiewicz, L.; Żelazny, M. Factors and Mechanisms Affecting Seasonal Changes in the Prevalence of Microbiological Indicators of Water Quality and Nutrient Concentrations in Waters of the Białka River Catchment, Southern Poland. Water Air Soil Pollut. 2016, 227, 302. [CrossRef] 
93. Cayanan, D.F.; Zheng, Y.; Zhang, P.; Graham, T.; Dixon, M.; Chong, C.; Llewellyn, J. Sensitivity of Five Container-grown Nursery Species to Chlorine in Overhead Irrigation Water. HortScience 2008, 43, 1882-1887. [CrossRef]

94. Lonigro, A.; Montemurro, N.; Laera, G. Effects of residual disinfectant on soil and lettuce crop irrigated with chlorinated water. Sci. Total Environ. 2017, 584, 595-602. [CrossRef]

95. Migliaccio, K.W.; Boman, B.; Clark, G.A. Treating Irrigation Systems with Chlorine. Univ. Fla. IFAS Ext. 2018, CIR1039, 7.

96. Lefevre, F.; Audic, J.; Ferrand, F. Peracetic acid disinfection of secondary effluents discharged off coastal seawater. Water Sci. Technol. 1992, 25, 155-164. [CrossRef]

97. Weisel, C.P.; Kim, H.; Haltmeier, P.; Klotz, J.B. Exposure estimates to disinfection by-products of chlorinated drinking water. Environ. Health Perspect. 1999, 107, 103-110. [CrossRef]

98. Carrasco, G.; Urrestarazu, M. Green chemistry in protected horticulture: The use of peroxyacetic acid as a sustainable strategy. Int. J. Mol. Sci. 2010, 11, 1999-2009. [CrossRef] [PubMed]

99. Allende, A.; Artés, F. UV-C radiation as a novel technique for keeping quality of fresh processed 'Lollo Rosso' lettuce. Food Res. Int. 2003, 36, 739-746. [CrossRef]

(C) 2019 by the authors. Licensee MDPI, Basel, Switzerland. This article is an open access article distributed under the terms and conditions of the Creative Commons Attribution (CC BY) license (http://creativecommons.org/licenses/by/4.0/). 